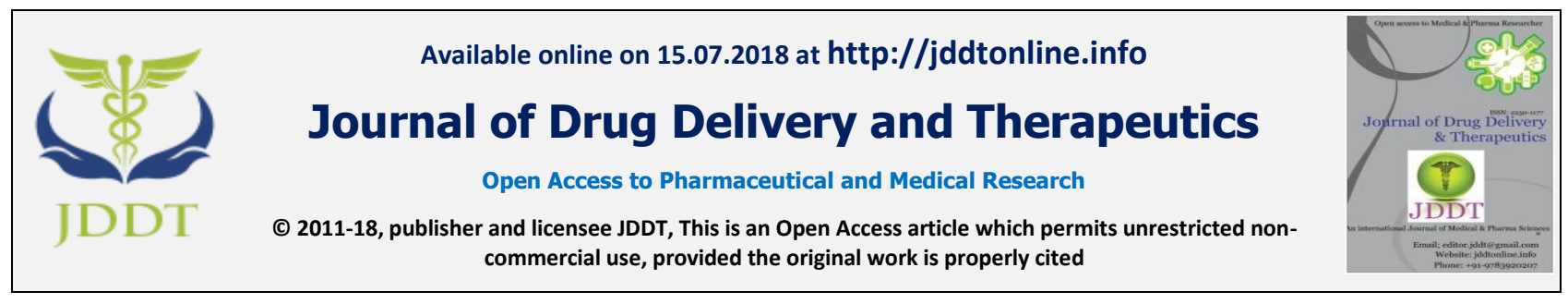

Open $\odot$ Access

Research Article

\title{
ANTIOXIDANT AND ANTI-INFLAMMATORY ACTIVITIES OF SALIX AEGYPTIACA BARK EXTRACT ATTRIBUTE TO ITS ANTICANCER EFFICACY
}

\author{
Mohd Nauman ${ }^{1}$, Lalita ${ }^{1,2}$, Raosaheb K. Kale ${ }^{1}$, Paulraj Rajamani ${ }^{2}$, Rana P. Singh ${ }^{1 *}$ \\ ${ }^{\mathbf{1}}$ School of Life Sciences, Jawaharlal Nehru University, New Delhi 110067, India \\ ${ }^{2}$ School of Environmental Sciences, Jawaharlal Nehru University, New Delhi 110067, India
}

\begin{abstract}
Salix aegyptiaca has been used traditionally from the ancient time for its beneficial effects. The protective action of this plant is not well understood so far. Oxidative stress and inflammation are generally linked with carcinogenesis. In the present study, antioxidant, anti-inflammatory and anticancer activities of hydroethanolic bark extract of Salix aegyptiaca have been studied. The results of DPPH assay indicated the free radical scavenging ability of the bark extract $(2-20 \mu \mathrm{g} / \mathrm{ml})$. The inhibition of ${ }^{\circ} \mathrm{OH}$ radical induced damage of pBR322 plasmid DNA by the extract $(20 \mu \mathrm{g} / \mathrm{ml})$ depicted its antioxidant property. This bark extract $(5-800 \mu \mathrm{g} / \mathrm{ml})$ exhibited the anti-inflammatory activity against heat induced protein denaturation. The medicinal property of $S$. aegyptiaca could be attributed to its free radicals scavenging ability and anti-inflammatory activity. Further, the extract (5-40 $\mu \mathrm{g} / \mathrm{ml})$ has shown anticancer activity against human hepatocellular carcinoma (HepG2) cells. However, the underlying mechanisms related to its anticancer effect need to be explored.
\end{abstract}

Keywords: Salix aegyptiaca, antioxidants, inflammation and hepatocellular carcinoma.

Article Info: Received 11 May, 2018; Review Completed 05 July 2018; Accepted 07 July 2018; Available online 15 July 2018

\section{Cite this article as:}

Nauman M, Lalita, Kale RK, Rajamani P, Singh RP, Antioxidant and anti-inflammatory activities of Salix aegyptiaca bark extract attribute to its anticancer efficacy, Journal of Drug Delivery and Therapeutics. 2018; 8(4):272-276 DOI: http://dx.doi.org/10.22270/jddt.v8i4.1786

*Address for Correspondence:

Rana P. Singh, School of Life Sciences, Jawaharlal Nehru University, New Delhi 110067, India. Email: ranaps@hotmail.com, Tel: +91 0112670 4503. Fax no: +91 01126742558

\section{INTRODUCTION}

Oxidative stress refers to the increased level of free radicals mainly reactive oxygen species (ROS) along with reactive nitrogen species (RNS) which cause damage to main cellular constituents like DNA, lipid and protein. Oxidative damage could lead to the initiation and development of several health complications such as diabetes, Alzheimer's disease, artherosclerosis, cardiovascular problems and various types of cancers ${ }^{1,2}$. ROS apart from damaging the cellular macromolecules, also lead to the secretion of chemotactic factors, stimulation of inflammatory process and several growth factors, and activation of many transcription factors and oncogenes ${ }^{3}$. Mitochondria, peroxisomes, cytochrome P450 metabolism and inflammatory responses are the endogenous sources of ROS generation ${ }^{4}$. The endogenous ROS production is scavenged by endogenous and exogenous antioxidants to avoid their detrimental effects.

Liver cancer is one of most common cancers worldwide. The developing countries in South-East Asia and Africa account for majority of these cases (more than $83 \%$ of total liver cancer cases) and cases are being increased in the industrially developed states ${ }^{5}$. According to GLOBOCAN, 2012, liver cancer has been reported as fifth most common cancer found in men and ninth in women. It ranked second according to the cancer mortality rate worldwide ${ }^{6}$. In 2012, there were around 782,500 new cases and 745,500 deaths found due to liver cancer globally? ${ }^{7}$. Salix aegyptiaca, commonly known as Musk willow, is a diecious flowering plant. It 
is mainly cultivated in province of $\operatorname{Iran}^{8}$. From ancient period, it has been traditionally used in Iran as cardioprotectant, gastroprotectant, laxative, sedative, nervonic, hypnotic, antihelmintic and vermifuge etc. ${ }^{9}$. Some recent reports showed anticancer activity of bark extract of $S$. aegyptiaca against human colon cancer cell lines and mouse model ${ }^{10,11,12}$.

In the present study, an attempt was made to study the free radical scavenging activity of hydroethanolic extract of $S$. aegyptiaca bark using DPPH assay, and its protecting role was also assessed by utilizing a method based on the induction of DNA damage in the form of single strand break by Fenton reagent generated $\mathrm{OH}$ radicals. The anti-inflammatory activity of this extract was also tested against heat induced protein denaturation. Further, the anticancer activity of the extract against human hepatocellular carcinoma cells, HepG2 was analyzed using cell viability assay.

\section{MATERIALS AND METHODS}

\subsection{Cell lines and reagents}

HepG2, a human hepatocellular carcinoma cell line, was obtained from National Centre for Cell Science (NCCS), Pune, India. Cells were grown in Dulbecco's modified Eagles medium (DMEM; Sigma, Saint Louis, MO, USA) supplemented with $10 \%$ fetal bovine serum (Gibco) and $1 \%$ penicillin-streptomycin (Himedia, India) at $37^{\circ} \mathrm{C}$ with $5 \% \mathrm{CO}_{2}$. S. aegyptiaca bark extract was dissolved in dimethyl sulfoxide (DMSO). The final concentration of DMSO in the medium was kept $0.1 \%$ $(\mathrm{v} / \mathrm{v})$ in all treatments including control. 1,1-Diphenyl-2picrylhydrazyl (DPPH), 3-(4,5-Dimethylthiazol-2-yl)2,5-diphenyltetrazolium bromide (MTT) and DMSO were obtained from Sigma (Saint Louis, MO, USA). pBR322 plasmid DNA was obtained from Thermo Fisher Scientific (Waltham, MA, USA). The rest of the chemicals used were procured from local firms (India) and were of highest purity grade.

\subsection{Preparation of hydroethanolic extract of $S$.} aegyptiaca stem bark

The stem bark of $S$. aegyptiaca was collected from the garden in Qazwin, Iran. The plant was identified by the botanist on the morphological basis and deposited (Sample no. 20150217) in the Department of Biotechnology, Jamia Millia Islamia, New Delhi, India. The bark was shade dried and powered to make a hydroethanolic extract (water: ethanol; 20:80 v/v). The powder was dissolved in solvent with ratio of $1: 10$ $(w / v)$. The solution was kept on continuous shaking at $30{ }^{\circ} \mathrm{C}$ for $48 \mathrm{~h}$ followed by the filtration through Whatman (No.1) filter paper. The supernatant was concentrated using rotary evaporator (Buchi R-300) at $45^{\circ} \mathrm{C}$ followed by the desiccation through lyophilizer.

\subsection{Determination of antioxidant activity by DPPH assay}

The free radical scavenging activities of S. aegyptiaca bark extract was measured by 1,1-Diphenyl-2picrylhydrazyl (DPPH) assay as carried out by G. C. Yen with slight modification ${ }^{13}$. Briefly, $1.3 \mathrm{ml}$ of methanolic solution of DPPH $(100 \mu \mathrm{M})$ was added to varying concentration of $S$. aegyptiaca bark extract (2$20 \mu \mathrm{g} / \mathrm{ml}$ ). The reaction was incubated at room temperature for $30 \mathrm{~min}$ in dark. The absorbance of the residual DPPH solution was determined at $517 \mathrm{~nm}$ in a UV-1800 spectrophotometer (Shimadzu Corp). BHT (Butylhydroxytoluene) was used as positive control. The percent DPPH radicals scavenging effect was calculated using following formula,

$$
\begin{aligned}
& \% \text { DPPH scavenging effect }= \\
& {\left[\left(\mathrm{Abs}_{\text {control }}-\mathrm{Abs}_{\text {sample }}\right) / \mathrm{Abs}_{\mathrm{control}}\right] \times 100}
\end{aligned}
$$

Where, $\mathrm{Abs}_{\text {control }}$ is the absorbance of DPPH radical + methanol and $\mathrm{Abs}_{\text {sample }}$ is absorbance of DPPH radical + sample extract/standard

\subsection{Determination of antioxidant activity by DNA nicking assay}

DNA nicking assay was carried out as described by Lee et al $2002^{14}$. Fenton reagent was used to generate the hydroxyl free radicals $\left({ }^{\circ} \mathrm{OH}\right)$ which reacts with pBR322 plasmid DNA and damages its structure. S. aegyptiaca bark extract $(20 \mu \mathrm{g} / \mathrm{ml})$ were added to the reaction mixture $(20 \mu \mathrm{l})$ containing $0.5 \mu \mathrm{g}$ of pBR322 and Fenton reagent $\left(30 \mathrm{mM} \mathrm{H}_{2} \mathrm{O}_{2}, 50 \mu \mathrm{M}\right.$ ascorbic acid, 80 $\mu \mathrm{M} \mathrm{FeCl})_{3}$. After incubation of $30 \mathrm{~min}$ at $37{ }^{\circ} \mathrm{C}$, analysis was done by running the samples on $1 \%$ agarose gel electrophoresis (Mini Sub-Cell GT, Biorad) followed by ethidium bromide staining. Gel documentation system (FluorChem HD2) was used to visualize the bands. The band intensity was analyzed by ImageJ software (NIH, USA).

\subsection{Determination of anti-inflammatory activity by protein denaturation assay}

The anti-inflammatory activity of $S$. aegyptiaca bark extract was studied by the method described by H. M. Arif Ullah ${ }^{15}$. The final reaction mixture contained $0.2 \mathrm{ml}$ of egg albumin, $2.8 \mathrm{ml}$ of phosphate buffer saline (PBS) and $2 \mathrm{ml}$ of varying concentrations of the S. aegyptiaca bark extract. The final concentration of extract was kept $50-800 \mu \mathrm{g} / \mathrm{ml}$. Sodium diclofenac was used as positive control. The tubes containing the mixture were incubated at $37^{\circ} \mathrm{C}$ for $15 \mathrm{~min}$ followed by heating at 70 ${ }^{\circ} \mathrm{C}$ for $5 \mathrm{~min}$. The tubes were allowed to cool and the absorbance was measured at $660 \mathrm{~nm}$. The percent inhibition of protein denaturation was calculated by using the following formula,

$\%$ Inhibition of protein denaturation $=\left[\left(\mathrm{Abs}_{\mathrm{control}}-\right.\right.$ $\left.\left.\mathrm{Abs}_{\text {sample }}\right) / \mathrm{Abs}_{\text {control }}\right] \times 100$

Where, $\mathrm{Abs}_{\text {control }}$ is the absorbance of control and $\mathrm{Abs}_{\text {sample }}$ is absorbance of extract/standard.

\subsection{Determination of cell viability by MTT assay}

Five thousand HepG2 cells were seeded in 96 well culture plate and incubated for $24 \mathrm{~h}$. Cells were then treated with DMSO or $5-40 \mu \mathrm{g} / \mathrm{ml}$ of $S$. aegyptiaca bark extract for $48 \mathrm{~h}$. Then $100 \mu \mathrm{l}$ of MTT solution $(5 \mathrm{mg} / \mathrm{ml}$ in PBS) was added to each well and incubated in $5 \%$ $\mathrm{CO}_{2}$ incubator for $4 \mathrm{~h}$. The MTT solution was removed without disturbing the cells and $100 \mu \mathrm{l}$ DMSO was added to each well to dissolve formazan crystals. After 
incubation of $10 \mathrm{~min}$ in dark, the wells were read in ELISA plate reader at $570 \mathrm{~nm}$ wavelength ${ }^{16}$.

\subsection{Statistical analysis}

The values were presented as mean \pm SEM. The mean and significance of the differences between the data pairs was calculated by t-test (SigmaPlot 8.0). A value of $p<0.05$ was considered significant.

\section{RESULTS}

\subsection{S. aegyptiaca bark extract scavenges DPPH free radicals}

A varying range of $S$. aegyptiaca bark extract concentration $(2-20 \mu \mathrm{g} / \mathrm{ml})$ exhibited the scavenging of DPPH radicals in concentration dependent manner. The $\mathrm{IC}_{50}$ value of the extract was found to be $17.71 \pm 0.34$. BHT was used as positive control for comparison. The results are shown in Figure 1.

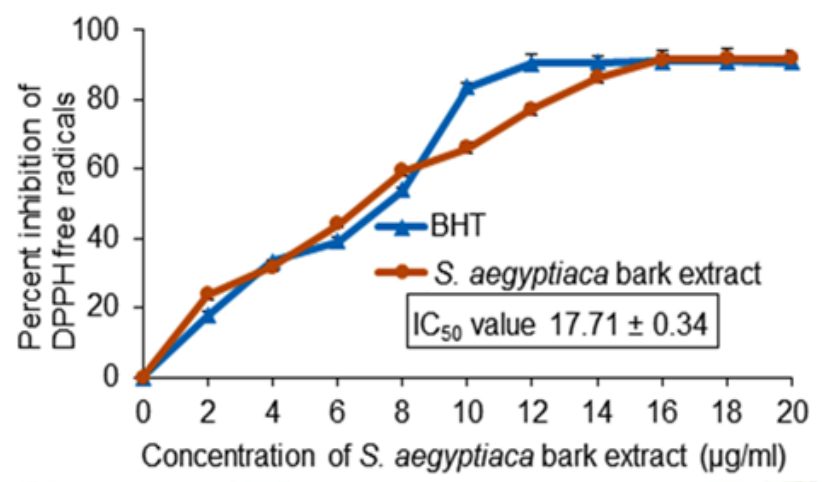

Figure 1: Free radical scavenging property of $S$. aegyptiaca barks extract. Data represents percent inhibition of DPPH free radicals through DPPH assay. Methanolic solution of DPPH was added to different concentrations of $S$. aegyptiaca bark extract (2-20 $\mu \mathrm{g} / \mathrm{ml})$. The reaction was incubated at room temperature for $30 \mathrm{~min}$ in dark. The absorbance of the residual DPPH solution was determined at $517 \mathrm{~nm}$. BHT was used as positive control. Values are represented as mean \pm SEM of three samples. Abbreviations: BHT; Butylhydroxytoluene.

\section{2 $S$. aegyptiaca bark extract protects DNA against OH radicals}

S. aegyptiaca bark extract $(20 \mu \mathrm{g} / \mathrm{ml})$ exhibited protective role against DNA damage induced by ${ }^{\circ} \mathrm{OH}$ radicals. For this assay, $20 \mu \mathrm{g} / \mathrm{ml}$ concentration was selected on the basis of $\mathrm{IC}_{50}$ value $(17.71 \pm 0.34)$ of this extract which was determined by DPPH assay. The damage was determined in terms of conversion of Form I of DNA (super coiled) into its Form II (relaxed) and Form III (linear). When the supercoiled pBR322 plasmid DNA incubated in presence of the Fenton reagent, the Form I of DNA was changed into for II (Lane: 3). The extent of conversion into Form III was relatively very small. The bark extract inhibited the conversion of Form I into Form II (Lane: 4) against Fenton reagent. The results can be seen in Figure 2.

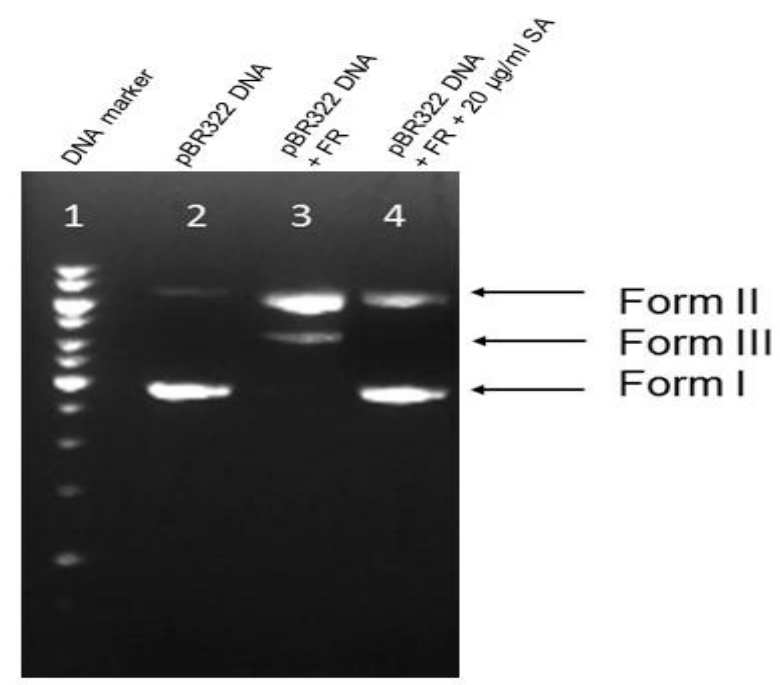

Figure 2: Antioxidant activity of S. aegyptiaca barks extract against ${ }^{\circ} \mathrm{OH}$ radicals causing DNA nick. Fenton reagent was added to $0.5 \mu \mathrm{g}$ of pBR322 plasmid DNA in absence or presence of $S$. aegyptiaca bark extract. The mixture was incubated for $30 \mathrm{~min}$ at $37^{\circ} \mathrm{C}$. After incubation the samples were analyzed by $1 \%$ agarose gel electrophoresis followed by ethidium bromide staining. Abbreviations: FR; Fenton reagent and SA; $S$. aegyptiaca bark extract.

3.3 S. aegyptiaca bark extract exhibits antiinflammatory activity

The anti-inflammatory activity of the extract $(50-800$ $\mu \mathrm{g} / \mathrm{ml}$ ) was determined by assessing its effect on inhibition of heat induced protein denaturation. The extract significantly inhibited the protein denaturation in concentration-dependent manner by $8.28 \%(\mathrm{p}<0.05)$, $18.25 \%(\mathrm{p}<0.005), 43.09 \%(\mathrm{p}<0.005), 50.53 \%(\mathrm{p}<$ $0.005)$ and $63.48 \%(\mathrm{p}<0.005)$ with the treatment 50, $100,200,400$ and $800 \mu \mathrm{g} / \mathrm{ml}$ of $S$. aegyptiaca bark extract. The results are depicted in Figure 3.

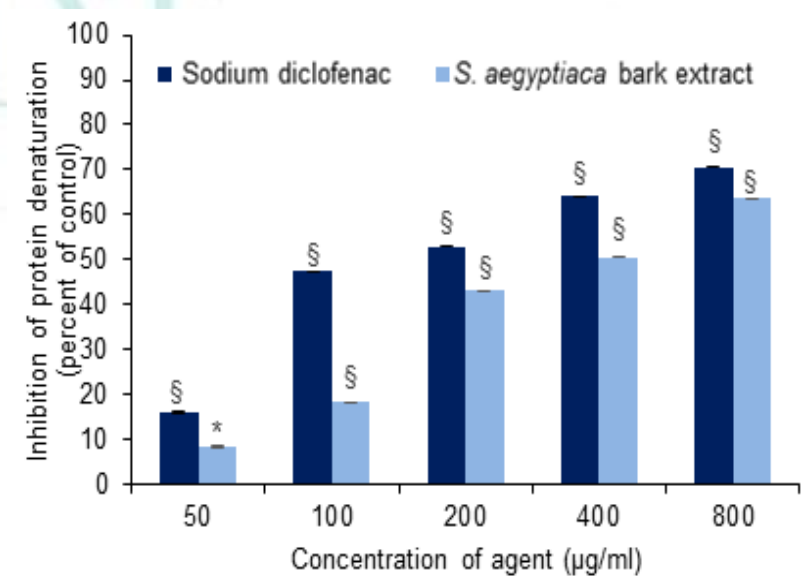

Figure 3: Anti-inflammatory activity of S. aegyptiaca barks extract. The final reaction mixture contained 0.2 $\mathrm{ml}$ of egg albumin, $2.8 \mathrm{ml}$ of phosphate buffer saline (PBS) and $2 \mathrm{ml}$ of varying concentrations of the $S$. aegyptiaca bark extract $(50-800 \mu \mathrm{g} / \mathrm{ml})$. The tubes containing reaction mixture were incubated at $37{ }^{\circ} \mathrm{C}$ for $15 \mathrm{~min}$ followed by heating at $70{ }^{\circ} \mathrm{C}$ for $5 \mathrm{~min}$. The tubes were allowed to cool and absorbance was measured at $660 \mathrm{~nm}$. Sodium diclofenac was used as a positive control. Values are represented as percent of 
control calculated by mean of three samples. ${ }^{\S}(\mathrm{p}<$ 0.005 ) represents significant changes relative to control.

\section{4 $S$. aegyptiaca bark extract decreases the cancer cell viability}

The treatment of $S$. aegyptiaca bark extract on HepG2 cells exhibited the decrease in cell viability at $48 \mathrm{~h}$ determined by MTT assay. The cell viability of HepG2 cells was significantly decreased by $33.79 \%(p<0.01)$ and $43.78 \%(p<0.01)$ with the treatment of 20 and 40 $\mu \mathrm{g} / \mathrm{ml}$ of bark extract, respectively. The results are shown in Figure 4.

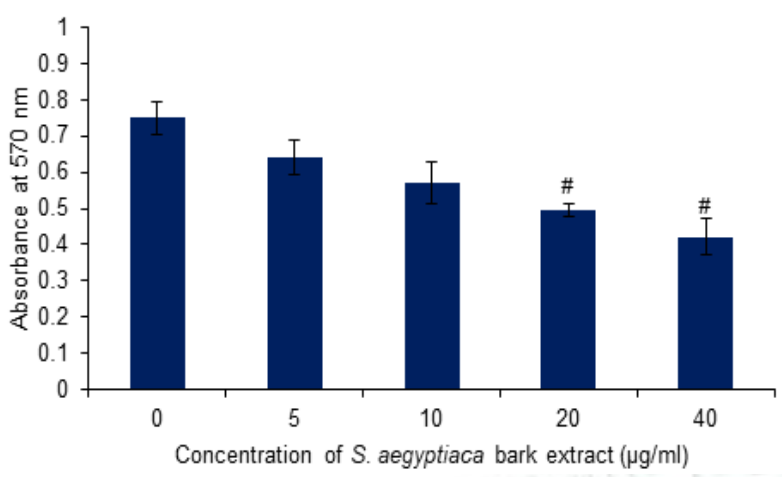

Figure 4: Inhibitory effect of $S$. aegyptiaca barks extract on viability of HepG2 cells. Cells were treated with DMSO or 5-40 $\mu \mathrm{g} / \mathrm{ml}$ of $S$. aegyptiaca bark extract for $48 \mathrm{~h}$. Then, $100 \mu \mathrm{l}$ of MTT solution $(5 \mathrm{mg} / \mathrm{ml}$ in PBS) was added to each well and incubated in $5 \% \mathrm{CO}_{2}$ incubator for $4 \mathrm{~h}$. The MTT solution was removed and $100 \mu \mathrm{l}$ DMSO was added to each well to dissolve formazan crystals. After incubation of $10 \mathrm{~min}$ in dark, the wells were read in ELISA plate reader at $570 \mathrm{~nm}$. Values are represented as mean \pm SEM of three samples. \# $(\mathrm{p}<0.01)$ represents significant changes relative to control.

\section{DISCUSSION}

ROS like ${ }^{1} \mathrm{O}_{2}$ (singlet oxygen), $\mathrm{O}_{2}{ }^{\cdot-}$ (superoxide), $\mathrm{H}_{2} \mathrm{O}_{2}$ (hydrogen peroxide), ' $\mathrm{OH}$ (hydroxyl), $\mathrm{NO}^{\circ}$ (nitric oxide), $\mathrm{HO}_{2}{ }^{\circ}$ (per hydroxyl), ROO' (peroxyl) and RO' (alkoxyl) are produced in mammalian body and result in the development of oxidative stress ${ }^{17}$. This excessive generation of ROS consequently leads to the cellular damage, which finally cause the induction of many pathological complications. S. aegyptiaca, being a plant with medicinal value, is supposed to possess antioxidant activity. Expectedly, in the present study, hydroethanolic extract of $S$. aegyptiaca scavenged the DPPH free radicals which indicated its antioxidant activity.

The DNA damage is considered to be one of the critical events in the cell damage. The ${ }^{\circ} \mathrm{OH}$ free radicals almost exclusively interact with DNA and cause strand breaks by removing the phosphate group from its backbone ${ }^{18}$. In the present study, the supercoiled pBR322 plasmid DNA was incubated in presence of the Fenton reagent along with or without the bark extract. Fenton reagent produces the $\mathrm{OH}$ free radicals which attack on supercoiled DNA (Form I) to convert it into relaxed DNA (Form II). The bark extract was found to inhibit the conversion of Form I into Form II (indicative of the single strand breaks). The protection of supercoiled DNA structure (Form I) could have occurred due to inactivation of ${ }^{\circ} \mathrm{OH}$ free radicals. The main detrimental effects are performed by $\mathrm{OH}$ free radicals being the most reactive free radical $^{19}$ with a shortest biological half-life $^{20}$. From the above findings, it could be concluded that $S$. aegyptiaca has property to scavenge $\cdot \mathrm{OH}$ and other free radicals. The antioxidant activity of this bark extract may be attributed by the presence of various phenolic compounds such as gallic acid, caffeic acid, vanillin, p-coumaric acid, myricetin, catechin, epigallatocatechin gallate, rutin and quercetin, which were determined by high performance liquid chromatography in bark extract of S. aegyptiaca ${ }^{21}$.

Now, it is well established that initiation and progression of many cancers originate from inflammation, hence identified as a hallmark of cancer thereby it has been turned out as one of the main focus for drug development studies. The inflammatory cells markedly contribute to the tumor microenvironment, promoting the neoplastic process and aiding in the cell proliferation, survival and migration ${ }^{22}$. The secretion of chemokines, cytokines, certain growth factors, and proteases by inflammatory cells could lead to the initiation and promotion of cancer ${ }^{23}$. In our study, $S$. aegyptiaca bark extract showed anti-inflammatory activity which might be ascribed to the anticancer potential of this extract as it exhibited decrease in cell viability of human hepatocellular carcinoma cells, HepG2. Hepatocellular carcinoma is the most common type of primary liver cancer (PLC) that accounts for approximately $75-90 \%$ of total $\mathrm{PLC}^{24}$ and a major health issue in developing countries.

The underlying mechanisms related to anticancer efficacy of $S$. aegyptiaca bark extract are yet to be explored, however some studies showed that the inhibition of colon cancer cells proliferation was mediated through G1/S cell cycle arrest and induction of apoptosis through p53 dependent pathway. Other pathways include the inhibition of PI3K/Akt and MAP Kinase pathways, and inhibition of epithelial to mesenchymal transition with the treatment of $S$. aegyptiaca bark extract ${ }^{11,12}$. Ethanolic extract of $S$. aegyptiaca bark exhibited chemopreventive efficacy against 1,2-dimethylhydrazine induced colon carcinogenesis in mice through antioxidant and antiinflammatory activities ${ }^{10}$. The above findings strongly indicate that $S$. aegyptiaca bark extract may show anticancer efficacy against hepatocellular carcinoma in animal models.

\section{CONCLUSION}

Overall, the present study suggests the potential of $S$. aegyptiaca bark extract to scavenge the free radicals, inhibit the inflammation and cell viability of hepatocellular carcinoma cells, HepG2. The antioxidant and anti-inflammatory activity of this extract might be responsible for its efficacy against several health complications including cancer. 


\section{Conflict of interest}

The authors declare that they have no conflict of interest.

\section{Acknowledgement}

We acknowledge financial support from UGC, New Delhi, India in the form of PhD Fellowship to Mohd
Nauman. We are also thankful to UGC-RNW, UPE-II as well DST-Purse funds to JNU, New Delhi. We are thankful to Dr. Rita Bagheri to provide us the plant sample and Dr. Mohammad Irfan Qureshi, Department of Biotechnology, Jamia Millia Islamia, New Delhi, India to identify the plant sample.

\section{REFERENCES}

1. Christen Y, Oxidative stress and Alzheimer disease, The American Journal of Clinical Nutrition, 2000; 71(2):621S9S.

2. Wu LL, Chiou CC, Chang PY, Wu JT, Urinary 8-OHdG: a marker of oxidative stress to DNA and a risk factor for cancer, atherosclerosis and diabetics, Clinica Chimica Acta, 2004; 339(1-2):1-9.

3. Kehrer JP, Free radicals as mediators of tissue injury and disease, Critical Reviews in Toxicology, 1993; 23(1):21-48.

4. Inoue M, Sato EF, Nishikawa M, Park AM, Kira Y, Imada I, Utsumi K, Mitochondrial generation of reactive oxygen species and its role in aerobic life, Current Medicinal Chemistry, 2003; 10(23):2495-505.

5. Gallicchio R, Nardelli A, Mainenti P, Nappi A, Capacchione D, Simeon V, Sirignano C, Abbruzzi F, Barbato F, Landriscina M, Storto G, Therapeutic strategies in HCC: radiation modalities, BioMed Research International, 2016, 2016:1-11.

6. Ferlay J, Soerjomataram I, Dikshit R, Eser S, Mathers C, Rebelo M, Parkin DM, Forman D, Bray F, Cancer incidence and mortality worldwide: sources, methods and major patterns in GLOBOCAN 2012, International Journal of Cancer, 2015; 136(5):E359-86.

7. Torre LA, Bray F, Siegel RL, Ferlay J, Lortet-Tieulent J, Jemal A, Global cancer statistics, 2012, CA: A Cancer Journal for Clinicians, 2015; 65(2):87-108.

8. Asgarpanah J, Phytopharmacology and medicinal properties of Salix aegyptiaca L, African Journal of Biotechnology, 2012; 11(28):7145-50.

9. Karimi I, Hayatgheybi H, Kamalak A, Pooyanmehr M, Marandi Y, Chemical composition and effect of an essential oil of Salix aegyptiaca L., Salicaceae,(musk willow) in hypercholesterolemic rabbit model, Revista Brasileira de Farmacognosia, 2011; 21(3):407-14.

10. Bounaama A, Enayat S, Ceyhan MS, Moulahoum H, Djerdjouri B, Banerjee S, Ethanolic extract of bark from Salix aegyptiaca Ameliorates 1, 2-dimethylhydrazineinduced colon carcinogenesis in mice by reducing oxidative stress, Nutrition and Cancer, 2016; 68(3):495-506.

11. Enayat S, Ceyhan MŞ, Başaran AA, Gürsel M, Banerjee S, Anticarcinogenic effects of the ethanolic extract of Salix aegyptiaca in colon cancer cells: involvement of $\mathrm{Akt} / \mathrm{PKB}$ and MAPK pathways, Nutrition and Cancer, 2013; 65(7):1045-58

12. Enayat S, Banerjee S, The ethanolic extract of bark from Salix aegyptiaca L. inhibits the metastatic potential and epithelial to mesenchymal transition of colon cancer cell lines, Nutrition and Cancer, 2014; 66(6):999-1008.

13. Yen GC, Chen HY, Antioxidant activity of various tea extracts in relation to their antimutagenicity, Journal of Agricultural and Food Chemistry, 1995; 43(1):27-32.

14. Lee JC, Kim HR, Kim J, Jang YS, Antioxidant property of an ethanol extract of the stem of Opuntia ficus-indica var. saboten, Journal of Agricultural and Food Chemistry, 2002; 50(22):6490-6.

15. Ullah HA, Zaman S, Juhara F, Akter L, Tareq SM, Masum $\mathrm{EH}$, Bhattacharjee R, Evaluation of antinociceptive, in-vivo $\&$ in-vitro anti-inflammatory activity of ethanolic extract of Curcuma zedoaria rhizome, BMC Complementary and Alternative Medicine, 2014; 14(1):346.

16. Burton JD, The MTT assay to evaluate chemosensitivity, Chemosensitivity, 2005; 1:69-78.

17. Nordberg J, Arner ES, Reactive oxygen species, antioxidants, and the mammalian thioredoxin system, Free Radical Biology and Medicine, 2001; 31(11):1287-312.

18. Von Sonntag C, The chemical basis of radiation biology, International Journal of Radiation Biology and Related Studies in Physics, Chemistry and Medicine,1987; 52(6):221-294.

19. Asmus KD, Möckel H, Henglein A, Pulse radiolytic study of the site of hydroxyl radical attack on aliphatic alcohols in aqueous solution, The Journal of Physical Chemistry, 1973; 77(10):1218-21.

20. Kale RK, Post-irradiation free radical generation: evidence from the conversion of xanthine dehydrogenase into xanthine oxidase, Indian Journal of Experimental Biology, 2003; 41(2):105-11.

21. Enayat S, Banerjee S, Comparative antioxidant activity of extracts from leaves, bark and catkins of Salix aegyptiaca sp, Food Chemistry, 2009; 116(1):23-8.

22. Coussens LM, Werb Z, Inflammation and cancer, Nature, 2002; 19, 420(6917):860-867.

23. Eiró N, Vizoso FJ, Inflammation and cancer, World Journal of Gastrointestinal Surgery, 2012; 4(3):62.

24. Center MM, Jemal A, International trends in liver cancer incidence rates, Cancer Epidemiology and Prevention Biomarkers, 2011; 20(11):2362-2368. 